\title{
Profil Pemahaman Konsep Siswa SMA dalam Menyelesaikan Masalah Program Linear Berdasarkan Perbedaan Gender
}

\author{
Yeny Kurmayningsih, Didik Hermanto, Mety Liesdiani
}

(C) 2020 JEMS (Jurnal Edukasi Matematika dan Sains)

This is an open access article under the CC-BY-SA license (https://creativecommons.org/licenses/bysa/4.0/) ISSN 2337-9049 (print), ISSN 2502-4671 (online)

\begin{abstract}
Abstrak:
Penelitian ini merupakan penelitian deskriptif kualitatif yang dilaksanakan pada kelas XI Subjek penelitian terdiri dari satu siswa laki-laki maskulin dan satu siswa perempuan feminim. Instrumen penelitian ini menggunakan Tes Gender, Pedoman Wawancara dan Tugas Penyelesaian Masalah (TPM). Teknik pengumpulan data penelitian ini menggunakan teknik wawancara berbasis tugas penyelesaian masalah. Teknik uji keabsahan data menggunakan triangulasi waktu. Teknik analisis data yang digunakan adalah reduksi, penyajian, dan kesimpulan. Berdasarkan analisis data yang telah dilakukan, diperoleh kesimpulan sebagai berikut. Profil pemahaman konsep siswa laki-laki maskulin dalam menyelesaikan masalah program linier meliputi: menuliskan apa yang diketahui dan apa yang ditanyakan yang dipertegas dengan adanya tanda tanya "?", memisalkan $\mathrm{x}$ dan y tanpa ditafsirkan ke grafik menggunakan kedua persamaan untuk mencari titik-titik $(x, y)$, menemukan kesalahan hitung dari mensubstitusikan titik-titik $(\mathrm{x}, \mathrm{y})$ yang telah ditentukan sendiri ke fungsi objektif, dan membaca kembali hasil pekerjaannya tanpa perhitungan ulang. Profil pemahaman konsep siswa perempuan feminim dalam menyelesaikan masalah program linier meliputi: menuliskan apa yang diketahui dan apa yang ditanyakan dengan memisalkan $\mathrm{x}$ dan $\mathrm{y}$, membentuk persamaan menggunakan pemisalan $\mathrm{x}$ dan $\mathrm{y}$ serta ditafsirkan ke bentuk grafik, mensubstitusikan titik-titik $(x, y)$ yang telah ditentukan sendiri ke fungsi objektif sehingga diperoleh hasil penyelesaian masalah, dan membaca kembali hasil pekerjaannya dengan menghitung ulang.
\end{abstract}

Kata Kunci: Pemahaman Konsep, Penyelesaian Masalah, Gender

\section{Pendahuluan}

\section{Abstract:}

This research is a qualitative descriptive study conducted in class XI. The research subjects consisted of one masculine male student and one feminine female student. The research instrument used a Gender Test, Interview Guidelines and Problem Solving Tasks (TPM). The data collection technique used in this research was the problem solving task-based interview technique. The technique of testing the validity of the data used time triangulation. The data analysis technique used was reduction, presentation, and conclusion. Based on the data analysis that has been done, the following conclusions are obtained. The profile of understanding the concept of masculine male students in solving linear programming problems includes: writing what is known and what is asked which is emphasized by the presence of a question mark "?", Taking $x$ and y without being interpreted on a graph using the two equations to find the points $(x, y)$, finds the arithmetic error from substituting the points $(x, y)$ that have been determined by yourself to the objective function, and reread the results of the work without recalculation. The profile of understanding the concept of feminine female students in solving linear program problems includes: writing down what is known and what is asked by considering $\mathrm{x}$ and $\mathrm{y}$, forming equations using the $\mathrm{x}$ and $\mathrm{y}$ assumptions and interpreting it into a graph, substituting the points $(x, y)$ has assigned itself to the objective function so that the results of problem solving are obtained, and re-read the results of their work by recalculating.

Keywords: Concept Understanding, Problem Solving, Gender

Pendidikan merupakan suatu upaya memperkaya atau menambah ilmu pengetahuan ba-

Yeny Kurmayningsih, STKIP PGRI Bangkalan

yeni.kurmayningsih@gmail.com

Didik Hermanto, STKIP PGRI Bangkalan

didikhermanto@stkippgri-bkl.ac.id

Mety Liesdiani, STKIP PGRI Bangkalan metyliesdiani@stkippgri-bkl.ac.id 
gi peserta didik melalui peran/ figure seorang pendidik atau media lain. Sesuai dengan UndangUndang Republik Indonesia No.20 Tahun 2003,

"Pendidikan adalah usaha dasar dan terencana untuk mewujudkan suasana belajar dan proses pembelajaran yang efisien agar siswa secara aktif dapat mengembangkan potensi dirinya khususnya dalam hal spritual keagamaan, pengendalian diri, kepribadian, kecerdasan, akhlak mulia, serta keterampilan yang dibutuhkan oleh dirinya, masyarakat, bangsa dan negara".

Kalimat di atas memiliki makna yang sangat luas, yang memberikan gambaran tentang apa, siapa, bagaimana, dan kemana atas segala sesuatu yang terkait dengan Pendidikan. Dengan adanya pendidikan, manusia dapat menjadi orang pandai dan dapat bersaing dalam berbagai bidang khususnya bidang akademik. Pendidikan bertujuan untuk mencerdaskan kehidupan bangsa, oleh karena itu pendidikan sangatlah penting dalam kehidupan suatu bangsa.

Dalam sistem pendidikan di Indonesia, matematika merupakan mata pelajaran yang wajib diperoleh oleh semua siswa di setiap jenjang pendidikan. Alasan adanya pendidikan matematika di semua jenjang karena matematika mempunyai keterkaitan dalam berbagai bidang ilmu (Lutfiyah, dkk, 2018). Siswa yang dikatakan lemah dan mengalami kesulitan dalam matematika dapat disebabkan oleh beberapa faktor, di antaranya adalah kurangnya pemahaman konsep dalam menyelesaikan suatu masalah. Konsep merupakan ide abstrak yang dapat digunakan untuk mengkalisifikasi atau menggolongkan sesuatu yang pada umumnya dinyatakan dengan suatu istilah atau rangkaian kata (Soedjadi, 2000). Hal ini dapat diartikan bahwa pemahaman konsep sangatlah penting untuk penyelesaian masalah matematika karena pemahaman konsep antara materi satu dengan materi lainnya saling berhubungan. Dengan adanya pemahaman konsep yang benar dapat menjadikan siswa aktif dan kreatif dalam menyesuaikan beberapa konsep matematika yang telah dikuasai sebelumnya.

Selain pemahaman konsep, faktor lain yang dapat mempengaruhi kemampuan siswa dalam menyelesaikan masalah matematika ialah faktor gender. Gender merupakan suatu kecenderungan peran laki-laki dan perempuan ke arah maskulin atau feminim. Peran yang dimaksud adalah peran sosial di masyarakat yang meliputi hak, kewajiban, kuasa, dan kesempatan antara laki-laki dan perempuan. Menurut Dagun, Save M (1992), gender terdiri dari 2 jenis yaitu maskulin dan feminim. Maskulin cenderung kurang teliti daripada feminim yang cenderung teliti dalam menyelesaikan masalah. Hal tersebut dapat diartikan bahwa aspek gender sangat erat berkaitan dengan proses penyelesaian masalah siswa, yang pada akhirnya berpengaruh pada hasil penyelesaian. Menurut Naziroh, dkk (2018), antara maskulin dan feminim memiliki keunggulan yang berbeda baik itu intelegensi, sikap, watak, dan sebagainya.

Berkaitan dengan penyelesaian masalah, Polya telah merumuskan 4 langkah penyelesaian masalah yang meliputi: memahami masalah, membuar rencana penyelesaian, melaksanakan rencana penyelesaian, dan memeriksa Kembali hasil penyelesaian yang diperoleh. Dalam menyelesaikan suatu masalah matematika pada tingkat sulit, sedang dan mudah diperlukan suatu pemahaman konsep yang baik bagi siswa. Sebaliknya, dari hasil penyelesaian siswa maka dapat ditentukan tingkat pemahaman konsep siswa. Untuk siswa yang memiliki pemahaman konsep yang baik akan menyelesaikan masalah matematika dengan mudah di berbagai tingkat kesulitan soal begitu pula sebaliknya (Fatqurhohman, 2016). Hal tersebut menunjukkan bahwa pemahaman konsep matematika memiliki peran sangat penting dalam menyelesaikan suatu permasalahan. Jika seorang siswa benar-benar memahami konsep dengan baik maka siswa 
tersebut akan dapat dengan mudah menyelesaikan masalah matematika dalam tingkatan berbeda dari yang mudah, sedang hingga ke masalah yang cukup sulit.

Beberapa uraian di atas memberikan sebuah gambaran bahwa antara pemahaman kosep, penyelesaian masalah, dan gender memiliki keterkaitan satu dengan yang lainnya, sehingga perlu digali lebih dalam lagi perihal keterkaitan antar ketiga aspek tersebut. Oleh karenanya, penelitian ini difokuskan pada profil pemahaman konsep siswa dalam menyelesaikan masalah program linier yang ditinjau dari perbedaan gender. Masalah yang digunakan adalah masalah program liner berbetuk soal cerita. Langkah penyelesaian masalah yang digunakan mengacu pada 4 langkah penyelesaian masalah menuurut Polya. Indikator pemahaman konsep yang digunakan untuk penelitian ini diadaptasi dari indikator pemahaman konsep menurut Suraji, dkk (2018). Indikator pemahaman konsep yang digunakan pada penelitian ini meliputi: 1) Mengungkapkan pengertian suatu konsep, 2) Menyajikan konsep dalam berbagai bentuk representasi matematis, 3) Menggunakan, memanfaatkan serta mengaplikasikan konsep atau algoritma dengan baik, dan 4) Menjelaskan keterkaitan konsep.

Selanjutnya, rumusan indikator pemahaman konsep siswa dalam menyelesaikan masalah berdasarkan 4 langkah penyelesaian masalah Polya dapat disajikan pada tabel berikut.

Tabel. 1. Indikator Pemahaman Konsep Siswa dalam Menyelesaikan Masalah Berdasarkan Tahapan Polya

\begin{tabular}{|c|c|c|c|}
\hline No. & Tahapan Polya & Indikator Pemahaman Konsep & Deskriptor \\
\hline 1. & Memahami masalah & $\begin{array}{l}\text { Mengungkapkan pengertian } \\
\text { suatu konsep. }\end{array}$ & $\begin{array}{l}\text { Menyebutkan pengertian } \\
\text { suatu konsep baik secara } \\
\text { lisan ataupun tulisan. } \\
\text { Menyebutkan apa yang } \\
\text { diketahui dalam soal baik } \\
\text { secara lisan ataupun tulisan } \\
\text { Menyebutkan apa yang } \\
\text { ditanyakan dalam soal baik } \\
\text { secara lisan ataupun tulisan }\end{array}$ \\
\hline 2. & $\begin{array}{l}\text { Membuat } \\
\text { perencanaan } \\
\text { penyelesaian } \\
\text { masalah }\end{array}$ & $\begin{array}{l}\text { Menyajikan konsep dalam } \\
\text { berbagai bentuk representasi } \\
\text { matematis }\end{array}$ & $\begin{array}{l}\text { Menuliskan informasi yang } \\
\text { diperoleh ke dalam model } \\
\text { matematika } \\
\text { - } \\
\text { Menuliskan algoritma } \\
\text { penyelesaian dari soal yang } \\
\text { akan diselesaikan }\end{array}$ \\
\hline 3. & $\begin{array}{l}\text { Melaksanakan } \\
\text { rencana } \\
\text { penyelesaian } \\
\text { masalah }\end{array}$ & $\begin{array}{l}\text { Menggunakan, memanfaatkan } \\
\text { serta mengaplikasikan konsep } \\
\text { atau algoritma dengan baik }\end{array}$ & $\begin{array}{l}\text { Menuliskan dan mendeskripsikan } \\
\text { komponen matematika dari suatu } \\
\text { masalah sesuai dengan algoritma }\end{array}$ \\
\hline 4. & $\begin{array}{l}\text { Memeriksa } \\
\text { Kembali hasil } \\
\text { penyelesaian } \\
\text { masalah yang telah } \\
\text { diperoleh }\end{array}$ & $\begin{array}{l}\text { Menjelaskan keterkaitan } \\
\text { konsep }\end{array}$ & $\begin{array}{l}\text { Melakukan pemeriksaan ulang } \\
\text { terhadap masalah yang telah } \\
\text { diselesaikan }\end{array}$ \\
\hline
\end{tabular}




\section{Metode}

Penelitian ini merupakan penelitian deskriptif kualitatif, yang bertujuan untuk mendeskripsikan profil pemahaman konsep siswa dalam menyelesaikan masalah yang ditinjau dari perbedaan gender. Penelitian ini dilaksanakan pada kelas XI MA AL-Hidayah Bangkalan. Subjek yang dipilih berdasarkan perbedaan gender, yang terdiri dari dua subjek yaitu seorang siswa laki-laki maskulin dan seorang siswa perempuan feminim. Pemilihan subjek dilakukan menggunakan angket gender. Selain itu penentuan subjek juga mempertimbangkan kesediaan siswa untuk dijadikan sebagai subjek penelitian dan kemampuan siswa dalam berkomunikasi, sehingga dapat memperlancar proses pengumpulan data.

Instrumen dalam penelitian ini meliputi instrument utama, yaitu peneliti sendiri dan intrumen pendukung yang terdiri dari: angket gender, tugas penyelesaian masalah (TPM), dan pedoman wawancara. Angket gender digunakan untuk pemilihan subjek penelitian. Tugas penyelesaian masalah (TPM) digunakan sebagai alat untu mengungkap data tentang pemahaman konsep siswa. Sedangkan pedoman wawancara digunakan sebagai panduan melakukan wawancara dalam rangka menggali lebih dalan tentang pemahaman konsep siswa berdasarkan hasil penyelesaian tugas yang dilakukan subjek. Uji validitas instrumen pendukung dilakukan melalui validasi ahli.

Teknik pengumpulan data pada penelitian ini meliputi teknik tes, yang digunakan dalam rangka pemilihan subjek dan teknik wawancara berbasis tugas penyelesaian masalah, yang digunakan sebagai pengumpulan data pemahaman konsep siswa dalam menyelesaikan masalah. Wawancara pada subjek dilakukan sesaat setelah subjek mengerjakan tugas penyelesaian masalah. Uji kredibilitas data dalam penelitian ini dilakukan dengan cara triangulasi waktu, yaitu membandingkan dua data yang diperoleh dari sumber yang sama dalam waktu yang berbeda. Analisis data dilakukan pada data yang telah diuji kredibilitasnya. Analisis data yang dilakukan menggunakan teknik analisis data menurut Moleong yang meliputi reduksi data, penyajian data, dan penarikan kesimpulan. Analisis data dilakukan pada setiap tahapan penyelesaian masalah menurut Polya.

\section{Hasil dan Pembahasan}

Berdasarkan hasil analisis data yang dilakukan, diperoleh hasil penelitian berupa profil pemahaman konsep siswa SMA dalam menyelesaikan masalah program linier berdasarkan perbedaan gender. Adapun instrumen tugas penyelesaian masalah (TPM)-1 dan tugas penyelesaian masalah (TPM)-2 yang digunakan untuk pengumpulan data pemahaman konsep siswa adalah sebagai berikut. 
Tugas Penyelesaian Masalah (TPM)

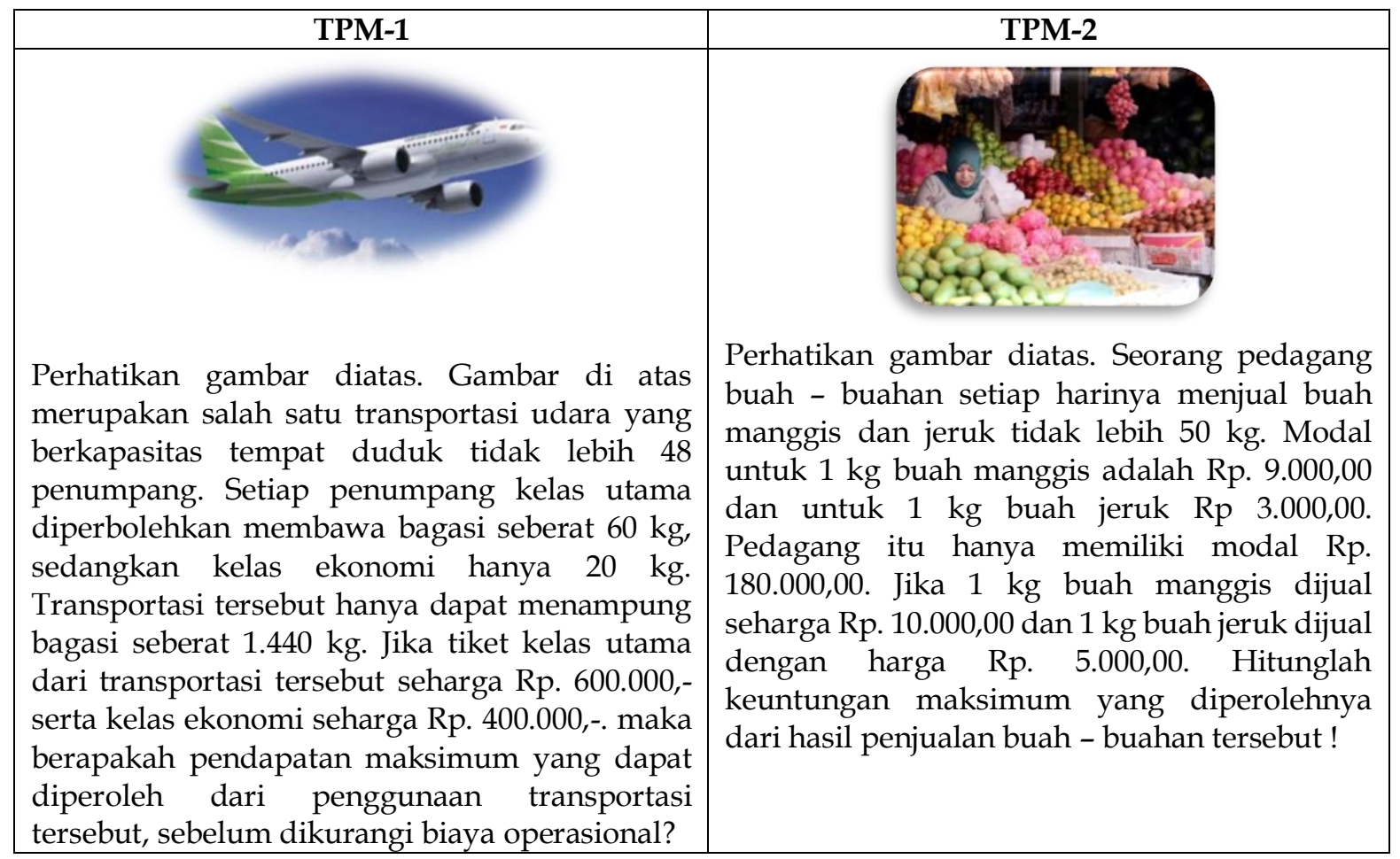

Berdasarkan hasil analisis data, profil pemahaman konsep siswa SMA dalam menyelesaikan masalah program linier dapat dideskripsikan sebagai berikut.

1. Profil Pemahaman Konsep Siswa Laki-laki Maskulin Dalam Menyelesaikan Masalah Program Linier

Dalam memahami masalah, siswa menyebutkan pengertian suatu konsep baik secara lisan ataupun tulisan dengan cara membaca teks dan mengamati gambar pada soal, menyebutkan apa yang diketahui dalam soal baik secara lisan maupun tulisan menggunakan bahasa sendiri, dan menyebutkan apa yang ditanyakan dalam soal baik secara lisan ataupun tulisan dengan diperjelas menggunakan tanda tanya "?". Kemudian dalam membuat perencanaan, siswa menuliskan model matematika dengan cara memisalkan $\mathrm{x}$ dan y terkait informasi yang diketahui dari soal tanpa ditafsirkan ke bentuk grafik. Selanjutnya siswa membuat perencanaan dengan cara menuliskan algoritma penyelesaian dari soal yang akan diselesaikan dengan menentukan titik - titik $(x, y)$ dan di substitusikan ke fungsi objektifnya untuk mendapatkan penyelesaian masalah.

Dalam melaksanakan rencana penyelesaian, siswa menuliskan dan mendeskripsikan komponen matematika dari suatu masalah berdasarkan algoritmanya yakni menggunakan kedua persamaan yang diperoleh dari soal dan mensubstitusikannya ke fungsi objektif. Kemudian siswa menuliskan dan mendeskripsikan komponen matematika dari suatu masalah sesuai dengan algoritma yaitu menemukan kesalahan dalam menghitung hasil penyelesaian masalah yang diperoleh dari mensubsitusi titik - titik $(x, y)$ ke fungsi objektif. Sedangkan dalam memeriksa kembali hasil yang diperoleh, siswa melakukan pemeriksaan ulang terhadap masalah yang telah diselesaikan dengan cara membaca dan melihat hasil perhitungan, namun siswa tidak menghitung ulang hasil yang dikerjakan. 


\section{Profil Pemahaman Konsep Siswa Perempuan Feminim Dalam Menyelesaikan Masalah Program Linier}

Dalam memahami masalah, siswa menyebutkan pengertian suatu konsep baik secara lisan maupun tulisan dengan cara membaca dan mengamati gambar di soal, kemudian menyebutkan apa yang diketahui dalam soal baik secara lisan ataupun tulisan dengan cara menuliskan informasi yang telah ditemukan sendiri dari soal dan memisalkan $\mathrm{x}$ atau y untuk direalisasikan menggunakan bahasa sendiri. Siswa menyebutkan apa yang ditanyakan dalam soal baik secara lisan ataupun tulisan dengan menggunakan tanda tanya "?" di akhir kalimat pertanyaan di soal. Selanjutnya dalam membuat rencana penyelesaian, siswa menuliskan model matematika dengan cara membentuk persamaan dari memisalkan $\mathrm{x}$ dan $\mathrm{y}$ terkait informasi yang diketahui di soal dan ditafsirkan ke bentuk grafik daerah penyelesaian. Kemudian, siswa menuliskan algoritma penyelesaian dari soal yang akan diselesaikan dengan cara menentukan titik $(x, y)$ dari kedua persamaan lalu disubstitusikan ke fungsi objektif sesuai dengan konsep permasalahan dalam soal.

Dalam melaksanakan rencana penyelesaian, siswa menuliskan dan mendeskripsikan komponen matematika dari suatu masalah sesuai dengan algoritma dengan cara kedua persamaan disubstitusikan ke fungsi objektif supaya mendapatkan penyelesaian masalah dari soal tersebut, kemudian menuliskan dan mendeskripsikan komponen matematika dari suatu masalah sesuai dengan algoritma dengan cara menemukan hasil penyelesaian masalahnya. Sedangkan dalam memeriksa kembali hasil yang diperoleh, siswa melakukan pemeriksaan ulang terhadap masalah yang telah diselesaikan dengan cara membaca dan menghitung ulang pekerjaannya untuk memastikan kebenaran jawaban.

\section{Simpulan}

Berdasarkan hasil analisis dan pembahasan, profil pemahaman konsep siswa SMA dalam menyelesaikan masalah program linier berdasarkan perbedaan gender dapat disimpulkan sebagai berikut. Profil pemahaman konsep siswa laki-laki maskulin dalam menyelesaikan masalah program linier meliputi: menuliskan apa yang diketahui dan apa yang ditanyakan yang dipertegas dengan adanya tanda tanya “?”, memisalkan x dan y tanpa ditafsirkan ke grafik

menggunakan kedua persamaan untuk mencari titik-titik $(x, y)$, menemukan kesalahan hitung dari mensubstitusikan titik-titik $(x, y)$ yang telah ditentukan sendiri ke fungsi objektif, dan membaca kembali hasil pekerjaannya tanpa perhitungan ulang.

Profil pemahaman konsep siswa perempuan feminim dalam menyelesaikan masalah program linier meliputi: menuliskan apa yang diketahui dan apa yang ditanyakan dengan memisalkan $\mathrm{x}$ dan $\mathrm{y}$, membentuk persamaan menggunakan pemisalan $\mathrm{x}$ dan $\mathrm{y}$ serta ditafsirkan ke bentuk grafik, mensubstitusikan titik-titik $(x, y)$ yang telah ditentukan sendiri ke fungsi objektif sehingga diperoleh hasil penyelesaian masalah, dan membaca kembali hasil pekerjaannya dengan menghitung ulang. 


\section{Daftar Rujukan}

Agustina, Candy Alfa. Rahayuningsih, Suesthi. Ngatiman. (2018). Analisis Keyakinan Diri (Self Efficacy) Siswa SMA Dalam Memecahkan Masalah Matematika Ditinjau Dari Perbedaan Gender. Majamath Volume 1 Nomor 2 September 2018.

Arikunto, Suharsimi. (2009). Dasar - Dasar Evaluasi Pendidikan. Jakarta : Bumi Aksara.

Asis, Musdalifah. Arsyad, Nurdin. Alimuddin. (2015). Profil Kemampuan Spasial Dalam Menyelesaikan Masalah Geometri Siswa Yang Memiliki Kecerdasan Logis Matematis Tinggi Ditinjau Dari Perbedaan Gender. Jurnal Daya Matematis, Volume 3 Nomor 1 Maret 2015. https:// ojs.unm.ac.id/JDM/article/view/1320/397

Azhar; Sudia, Muhammad; , Kadir;. (2016). Profil Penalaran Matematis Siswa SMA yang Bergaya Kognitif Impulsif-Reflektif dalam Memecahkan Masalah Matematika Ditinjau dari Perbedaan Gender. Jurnal Pembelajaran Berpikir Matematika, Vol. 1, No. 1, Februari 2016: 2130, 21-30.

Jaelani; , Retnawati; , Heri;. (2016). the callenges of junior high school mathematic teachers in implementing the problem-based learning for improving the higher-order thinking skills. journal of counseling $\mathcal{E}$ education. vol.4, issue 3, 1-13

Arini Windiasih Putri. (2017). Profil Pemahaman Siswa Kelas VII SMP Dalam Menyelesaikan Masalah Himpunan Ditinjau Dari Gaya Kognitif. Skripsi S1 (tidak dipublikasikan), 8

Dagun, Save M.;. (1992). Maskulin dan Feminin. Jakarta: PT. Rineka Cipta

Dr. Djadir, M.Pd.; Minggi, M.Pd., Dr. Ilham; , Ja'faruddin, S.Pd.,M.Pd.; Zaki, S.Si, M.Si., Ahmad ; Sidjara , S.Si.,M.Si., Sahlan;. (2017). Sumber Belajar Penunjang PLPG 2017 Mata Pelajaran/Paket Keahlian Matematika

Fatqurhohman. (2016). Pemahaman Konsep Matematika Siswa Dalam Menyelesaikan Masalah Bangun Datar. Jurnal Ilmiah Pendidikan Matematika, Vol. 4 No. 2, hlm 127-133

Kalsum, Ummi; Hasbi, Muh.; Ismaimuza, Dasa;. (2016). Profil Pemecahan Masalah Sistem Persamaan Linear Dua Variabel Siswa Berkemampuan Sedang SMA Al-Azhar Kelas X Palu Ditinjau Dari Perbedaan Jenis Kelamin. AKSIOMA Jurnal Pendidikan Matematika, Vol. 5, No. 3, Desember 2016 Disajikan dalam Seminar Nasional Pendidikan Matematika ke-4 Universitas Tadulako, 4 Desember 2016

Kurniasi, Eka Rachma;. (2016). Profil Pemahaman Matematis Mahasiswa Pendidikan Matematika Ditinjau dari Jenis Kelamin. Jurnal Prima ISSN: 2301-9891 Vol. V, No. II, Juli 2016 , 1

Lutfiyah, Siti Aminah; , Kartinah; Rubowo, Maya Rini;. (2018). Profil Pemaham Konsep Siswa Laki - Laki dalam Pemecahan Masalah Matematika Menurut Tahapan Polya. Seminar Nasional Matematika Dan Pendidikan Matematika (3th SENATIK) Program Studi Pendidikan Matematika FPMIPATI-Universitas PGRI Semarang 
Mallisa, Particia Lusi; Tahmir, Suradi; Minggi, Ilham;. (2015). Profil Pemecahan Masalah Matematika Berdasarkan Taksonomi SOLO Ditinjau Dari Gaya Kognitif dan Gender.

Marmoah, S. (2017). Profil Gender dan Pendidikan Kota Jambi. Harkat an-Nisa: Jurnal Studi Gender dan Anak, Vol. II, No. 1, 2017, 62.

Moleong, M.A., Prof. Dr. Lexy J.;. (2016). Metodelogi Penelitian Kualitatif. Dalam M. P. Moleong, Metodelogi Penelitian Kualitatif Edisi Revisi (hal. 330). Bandung: PT Remaja Rosdakarya.

Naziroh, Irmu Afin; , Suharto; Yudianto, Erfan; , Hobri; Murtikusuma, Randi Pratama;. (2018). Proses Berpikir Aljabar Siswa dalam Memecahkan Permasalahan Matematika Berdasarkan Kemampuan Aljabar dan Gender. Kadikma, Vol. 9, No. 2, hal.136-144, Agustus 2018

Polya, George; (1973). How to Solve It - A New Aspect of Mathematical Method (Second edition). New Jersey: Princeton University Press.

Sugiyono. (2012). Metode Penelitian Pendidikan. Bandung: Alfabeta

Risywandha, Ihmah; Khabibah, Siti;. (2018). Literasi Matematika Siswa SMA Kelas X dalam Menyelesaikan Soal Model PISA Ditinjau dari Perbedaan Gender. Jurnal Ilmiah Pendidikan Matematika Volume 2 No.7 Tahun 2018 ISSN :2301-9085

Suharsimi Arikunto. (2009). Dasar - Dasar Evaluasi Pendidikan. Jakarta : Bumi Aksara.

Suraji, Maimunah, \& Saragih, S. (2018). Analisis Kemampuan Pemahaman Konsep Matematis dan Kemampuan Pemecahan Masalah Matematis Siswa SMP pada Materi Sistem Persamaan Linear Dua Variabel (SPLDV). Suska Journal of Mathematics Education (p-ISSN: 2477-4758 |e-ISSN: 2540-9670) Vol. 4, No. 1, 2018, Hal. 9-16

Wabula, Darsih; , Jafar; Cahyono, Edi;. (2017). Analisis Pemahaman Konsep Limit Fungsi pada Siswa SMA Berdasarkan Jenis Kelamin. Seminar Matematika dan Pendidikan Matematika UNY 2017 ISBN. 978-602-73403-2-9 (Cetak) 978-602-73403-3-6 (On-line), PM-191. 